\title{
Historická účetní terminologie v českých zemích v pozdním středověku a raném novověku: příspěvek k diskuzi
}

Pavla Slavíčková / pavla.slavickova@upol.cz

Katedra aplikované ekonomie, Filozofická fakulta, Univerzita Palackého v Olomouci

\begin{abstract}
In the Middle Ages and early modern period, a specific accounting system was used in the Czech lands, known as so-called administrative accounting. The accounting categories and principles of this system were not the same as those used by single-entry and double-entry bookkeeping. The aim of the article is to show with selected accounting terms and categories their semantic variability and thereby start a discussion on accounting terminology that has been thus far absent in the Czech environment.
\end{abstract}

\section{Keywords}

accounting; history; terminology; Middle Ages; early modern period; Czech lands, towns 
Počátky moderní účetní terminologie je možné podobně jako u jiných oborů hledat v druhé polovině 19. a na počátku 20. století. Mezi ty osobnosti, kterým vděčíme za současné termíny, jako je účet, směnka, účetní bilance, účetní závěrka apod. patří Antonín Skřivan nebo Josef Pazourek. ${ }^{1}$ Vedle řady učebnic a několika teoretických studií se jako zásadní pro tento příběh jeví v roce 1900 vznik odborného periodika specializovaného pouze na účetnictví s názvem Účetni listy, na němž měl největší zásluhu zmíněný Josef Pazourek, ${ }^{2}$ vydání Ottova obchodniho slovniku mezi léty 1912 a $1925^{3}$ a pak zejména zásluhou Josefa Fuksy vydání monumentálního jedenáctidílného Slovniku obchodně-technického, účetního a daňového mezi léty 1929 a $1940 .{ }^{4}$ Nová legislativní úprava a sjednocení obsahu výuky účetnictví definitivně převedly účetní pojmy z dosavadní účetní teorie i do účetní praxe, ve které již pevně zakotvily. ${ }^{5}$ Správné označení konkrétního účetního jevu, kategorie nebo principu je dnes základní podmínkou pro porozumění konkrétní skutečnosti. Naopak přenesení současných výrazů pro označení věcí minulých může být zavádějící, stejně jako používání historických pojmů, jejichž význam je v současnosti jiný. Cílem příspěvku je za použití původních účetních záznamů na příkladu několika účetních kategorií a termínů z období pozdního středověku a raného novověku ukázat nutnost diskuze o historické účetní terminologii v českých zemích, která v naší historiografii doposud chyběla.

Základem středověkého a raně novověkého účetnictví byla evidence př́jmů a vydání, jak jsou tyto operace $\mathrm{v}$ pramenech nejčastěji označovány. Jako Hlavni rejstřrk obecnich př́jmů a vydání byla pojmenována nejstarší účetní kniha dochovaná v Kutné Hoře z let 1454-1455, ${ }^{6}$ přičemž řada Knih obecnich přijmů a vydáni se v tomto městě táhne po celé 16., 17. a část 18. století. I když vazby zejména nejstarších knih takovéto označení přímo nenesou, termín je odvozen z textu, který knihy uvozuje, případně z nadpisů oddílů a o jeho původnosti tedy nemůže být pochyb. ${ }^{7}$ Stejné spojení můžeme vidět i na městských účtech z Mělníka označených jako Registra přímů a vydáni obecních z let 1599-1607, nebo třeba v Uherském Brodě, jehož nejstarší účetní knihy z let 1567 a 1569 nesou název

1 Slavíčková, Pavla - Puchinger, Zdeněk: Účetnictví jako věda: významné osobnosti a díla. In: Malé dějiny účetnictví. Edd. Puchinger, Z. - Slavíčková, P., Olomouc 2014, s. 11-34.

2 Zelenka, Vladimír: Identifikace etap vydáváni odborného účetniho časopisu (Mezniky vydáváni časopisu Účetni listy). Český finanční a účetní časopis 10, 2015, č. 2, s. 70-94.

3 Pazourek, Josef (ed.): Ottův obchodni slovnik, Praha: 1. díl A-J, 1912-1913; 2. díl K-N, 1913-1916, 3. díl O-Ž, 1916-1925.

4 Fuksa, Josef (ed.): Slovnik obchodně-technický, účetni a dañový: obchodnè-technická prakse a teorie zvláště z oboru otázek účetních, finančně právnich a dañových se zuläštním zřetelem $k$ soukromo-ekonomickým potřebám prưmyslu, obchodu, živnosti a zemèdèlství. Praha: 1. díl, 1929; 2. díl, 1930, 3. díl, 1931, 4. díl, 1932, 5. díl, 1933; 6. díl, 1934; 7. díl, 1935; 8. díl, 1936; 9. díl, 1937; 10. díl, 1939; 11. díl, 1940.

5 Slavíčková, Pavla: Právni úprava účetnictvi v českých zemích v minulosti. Acta Universitatis Brunensis. Iuridica 449, Brno 2013, s. 295-304.

6 Státní okresní archiv Kutná Hora, Archiv města Kutná Hora, Hlavní rejstřrík obecních př́ijmů a vydání $1454-1455$, inv. č. 545.

7 Viz např. „Vydání peněz obecních městských z napředpsaných př́ijmův“. Tamtéž, Kniha obecních př́ijmů a vydání 1677, inv. č. 584.

8 Státní okresní archiv Mělník, Archiv města Mělník, Registra př́immů a vydání obecních, 1599-1607, inv. č. 151 . 
Repertorium na městské př́jmy a vydáni.$^{9}$ Stejné termíny jsou běžně používány i v obsahu účetních knih, at’ už nadpisech, nebo samotném textu. Pojmy př́imy a vydáni tak lze považovat za soudobé ustálené české výrazy pro latinská Percepta a Distributa a německá Einkommen a Ausgabe, které se ostatně mnohdy vyskytují paralelně, jak můžeme doložit třeba na účtech v Jihlavě, ${ }^{10}$ nebo Lounech ${ }^{11}$. Uvedené výrazy přejímají proto téměř bez výjimky i archiváři při zpracování středověkých a raně novověkých účetních knih, což dokumentuje třeba př́klad Znojma, kde původně latinské a německé záznamy jsou v inventáři označeny jako Malé rejstř́ky př́jmů a vydáni. ${ }^{12}$

Přejímání pojmů př́jmy a vydáni do odborných textů však může být z hlediska účetnictví zavádějící. Zejména termín př́jem má totiž v současnosti v účetnictví ustálený význam a označuje reálný (uskutečněný) peněžní tok ve smyslu přírůstku peněžních prostředků. Jeho protiváhou je pojem výdaj, který označuje úbytek těchto prostředků. Operace, které byly zaznamenávány do středověkých a raně novověkých účtů, jsou však díky svému charakteru spíše tzv. výnosy. Ty zahrnují nejen příjmy, tedy ty operace, které již proběhly, ale i budoucí, k jejichž naplnění (úhradě) teprve dojde na základě nároku. Mezi tzv. „př́ímy“ byly totiž ve středověkých a raně novověkých pramenech uváděny právě i operace tohoto typu. Konkrétně třeba ve Stř́ibře mezi takovými záznamy v Knize počtů můžeme najít půjčku panu děkanovi „,když jel do Domažlic“, 13 ještě běžnější jsou však zápisy o prodeji produktů či věcí, jejichž úhrada byla odložena nebo rozpočtena do postupných splátek. ${ }^{14}$

Opakem výnosů jsou náklady, u kterých platí stejná pravidla. Obecně se lze domnívat, že u těchto operací je ve středověkých a raně novověkých účtech poměr reálně uskutečněných a odložených operací nižší, s ohledem na charakter tohoto účetnictví však určité pochybnosti při interpretaci těchto záznamů zůstávají na místě. ${ }^{15} \mathrm{Z}$ hlediska účetní teorie je totiž rozdíl mezi tím, zda se jedná o př́imy a výdaje či výnosy a náklady, zcela zásadní. Pouze rozdílem mezi výnosy a náklady lze totiž zjistit výsledek hospodaření v podobě informace o zisku či ztrátě, zatímco porovnání př́jmů a výdaju je základem pro výkaz o peněžnich tocích, tzv. cash flow, tedy kolik peněz účetní jednotka vyprodukovala a jakým způsobem je užila. ${ }^{16}$ Cash flow tak přináší obraz o finanční situaci podniku a úrovni jeho finančního řízení, na rozdíl od výsledku hospodařeni, který nám vypovídá o úspěšnosti (rentabilitě) daného subjektu. ${ }^{17}$

9 Státní okresní archiv Uherské Hradiště, Archiv města Uherský Brod, Repertorium na městské př́íjmy a vydání 1567, inv. č. 75; Repertorium na městské př́íjmy a vydání 1569, inv. č. 76.

10 Státní okresní archiv Jihlava, Archiv města Jihlava, Hlavní účet př́immů a vydání (General Raittung alles Einkomens und Ausgab gemainer stat Iglaw), inv. č. 26, 1564-1565.

11 Státní okresní archiv Louny, Archiv města Louny, Liber rationum, 1450-1472, sign. I E 9, inv. č. 567.

12 Státní okresní archiv Znojmo, Archiv města Znojmo, knihy č. 301-308, 311-313, 315.

13 Státní okresní archiv Tachov, Archiv města Stříbro, Kniha počtů 1589-1597, inv. č. 29, fol. 33v.

$14 \mathrm{~K}$ tomuto detailně viz Slavíčková, Pavla: Účetnictvi mezi tradici a racionalitou v českých zemích od středověku do počátku 18. století, Praha 2017, s. 139-184.

15 Více opět tamtéž.

16 Podnikatel, www.podnikatel.cz, citováno 27. 4. 2018.

17 Detailně k účetní uzávěrce viz Slavíčková, Pavla: „Ze všeho pořádně počty činiti. “ Různé přístupy k uzavírání účtů na přelomu středověku a raného novověku. In: Středověké město: politické proměny a sociální inovace. Edd. Nodl M., Malaníková Antonín M., Mozejko B. Praha 2019, s. 207-222. 
Z výše řečeného vyplývá, že i pojmy zisk a ztráta nelze v souvislosti s účetnictvím používat nahodile. Jako zisk je v současnosti označován jakýkoliv kladný výsledek hospodaření. Zisk, stejně jako ztrátu ve smyslu záporného výsledku hospodaření, lze zjistit pouze při zohlednění všech operací, nejen těch již realizovaných, ale i těch očekávaných za dané účetní období. ${ }^{18}$ Účetní technika používaná u nás ve středověku a raném novověku tento přístup fakticky neumožňuje. Ostatně pozdně středověké a raně novověké účty uvedené termíny nepoužívají, zmíněné součty jsou v účtech obvykle označovány jako Summa (Summa př́jmů, Summa vydáni), Summa summarum ve smyslu celkového součtu apod., a to i přes to, že (třeba na rozdíl od pojmů účet či účetnictvi) se tato slova ve staročeštině i v souvislosti s ekonomickými aktivitami běžně vyskytovala. Závazek, že „poručniky činím ... na zisk i na ztrátu“ nalezneme třeba v Knize drnovské. ${ }^{19}$ Chápán byl však v obecném smyslu jako jakýkoliv prospěch, výdělek či užitek, nikoliv jako jasně definovaná účetní kategorie. ${ }^{20}$ Podobně ztráta znamenala jakoukoliv škodu v širokém smyslu slova, častěji, jak můžeme vidět třeba v soudním zápisu z roku 1511, kde doslova stoji, „,nemaje z toho gruntu žádného zisku“ “21, v souvislosti se soudními spory než finančními prostředky. ${ }^{22}$

Na okraj bych zmínila pojmy aktiva a pasiva, historiky v souvislosti s účetnictvím mnohdy až nadužívaná, která však nemají v historických záznamech v námi sledované době žádné opodstatnění. Jedná se o účetní kategorie ryze moderní, jejichž význam se v různých účetních soustavách může lišit. V obou případech se jedná o majetek (zdroje), pro potřeby podvojného účetnictví nahlížený ze dvou různých úhlů: v případě aktiv se jedná o majetek dle jeho struktury, zatímco u pasiv dle jeho původu (zdroje krytí). Aktiva proto dále rozlišujeme na krátkodobá (oběžná) a dlouhodobá, a ty dále na hmotný, nehmotný a finanční majetek. Oproti tomu pasiva se v základu dělí na vlastní a cizí kapitál. Pro srovnání, v jednoduchém účetnictví 19. století však byly oba pojmy chápány odlišně, jako Activum bylo označováno tzv. jměni vi̊bec, které mělo různou strukturu dle ekonomického zaměření daného subjektu, zatímco termín Passiva označoval dluhy vuibec. Čisté jměni (reine Activa) se zjistilo odečtením dluhů vỉbec od jměni vỉbec. ${ }^{23}$

Nejednotnost při interpretaci středověkého a raně novověkého účetnictví se však netýká jen účetních pojmů a kategorií, ale i samotných účetních knih. Typologie účetních knih ve vztahu k jejich obsahu a roli (postavení) v konkrétní účetní soustavě byla přitom i v minulosti v různých účetních soustavách ustálená (závazná) podobně jako je tomu v současnosti u účetních termínů (odborného pojmosloví). Př́íladem může být uvedené jednoduché účetnictví, které v době své největší popularity bylo jasně definováno systémem knih řádných a mimořádných, přičemž první skupinu tvořil popisnik (inventár), denik (prvni zápisnik) a hlavni kniha. Každá z těchto knih měla jasně definovaný obsah,

18 Janhuba, Miloslav: Teorie účetnictví. Praha 2010.

19 Brandl, Vincenc (ed.): Kniha Drnovská. Praha 1972, 24/151.

20 Bělič, Jaromír - Kamiš, Adolf - Kučera, Karel: Malý staročeský slovnik. Praha 1979; Vokabulář webový, https://vokabular.ujc.cas.cz/default.aspx, citováno 20. 3. 2018.

21 Kalousek, Josef (ed.): Archiv český, 18, Praha 1900, s. 378.

22 Další př́íklady viz Vokabulář webový, https://vokabular.ujc.cas.cz/default.aspx, citováno 20. 3. 2018.

23 Skřivan, Antonín: Nauka o kupeckém účetnictvi. Účetnictvi jednoduché a knihy mimořádné. Praha 1874, s. 174. Podobně i u dalších autorů viz Puchinger, Z. - Slavíčková, P.: Malé dějiny. 
mnohdy i předtištěné formuláře, a s ním i spojenou roli v dané účetní soustavě. ${ }^{24}$ Systém knih jako základ účetní techniky popsal i Luca Pacioli, autor první tištěné publikace o podvojném účetnictví, která byla vydána v roce $1494 .{ }^{25} \mathrm{~V}$ tomto případě se jednalo taktéž o tři knihy, memoriál (zápisnik), žurnál (denik) a hlavni (bilanční) knihu spolu s počátečním inventářm. Jádro systému, tedy známý princip podvojného zápisu, se prováděl v deníku, do kterého byly přepisovány na stranu Per (debitor, debtor) a A (creditor). ${ }^{26}$ Uvedený systém byl přitom pravděpodobně znám o několik desítek let dříve, první dochované zápisy vedené tímto způsobem pochází z italských měst z první poloviny 14. století, ${ }^{27}$ a zůstal v základu neměnný po dlouhá následující století.

Středověké a raně novověké účetnictví v českých zemích žádnou takovouto soustavu knih neznalo. Spektrum a variabilita účetních knih byla v tomto období obrovská, pokud bychom například vedle sebe postavili účetnictví Brna ${ }^{28}$ a Loun ${ }^{29}$, budeme nějaké průsečíky hledat jen obtížně. ${ }^{30}$ Nutno podotknout, že na rozdíl od uvedených měst, jejichž účetnictví je v českých podmínkách oproti jiným skutečně specifické, většina českých, moravských a slezských měst, stejně jako dalších subjektů se v tomto období ustálila na určitých společných účetních principech. Základní vhled, i když samozřejmě nikoliv vyčerpávající, do typologie účetních knih, nám poskytli Jiří Čarek a Bořivoj Lůžek. Ponecháme-li stranou knihy berní a poplatkové a knihy šacunků rozlišují autoři s odkazem na návrh Františka Hoffmanna, který se opíral o strukturu jihlavských materiálů, mezi knihami městských počtů tzv. hlavní knihy a rejstřríky, zvláštní účetní knihy městské správy a zvláštní účetnî knihy městského podnikání. ${ }^{31}$ Do první uvedené skupiny byl zařazen hlavní účet př́jmmo̊ a vydání, kniha počtů, knihy týdenních účtů o př́ijmech a vydáních, počet hlavní, počty městské, registra hlavní peněžitá, registra memoriální a úřední, registra účetní, registra příjmů - vydání, rejstřík příjmů a vydání, rejstříky dluhů městských, Liber rationarum,

24 Více Puchinger, Z. - Slavíčková, P.: Malé dějiny.

25 Janhuba, Miloslav (ed.): Magister Luca Pacioli (Patiolus): Tractatus XI. particularis, de computis et scripturis, část knihy Summa de Arithmetica, geometria, proportioni et proportionalita, vydané v listopadu 1494 Benátkách. In: Základy teorie účetnictví, Praha 2005, s. 170-216. Z literatury např: Antinori, Carlo - Hernández Esteve, Esteban: 500 anni de partita doppia e letteratura contabile, 1494-1994: due recenti studi sulla Summa di Fra Luca Pacioli. Roma 1994; Slavíčková, Pavla: The Double-Entry Accounting System Before 1800 as an Example of a Cultural Transfer Failure. In: Processes of Cultural Exchange in Central Europe 1200-1800. Ed. Čapská, Veronika, Opava 2014, s. 129-147.

26 Více viz Tractatus XI. kap. 11.

27 Lee, Alan Geoffrey: The Development of Italian Bookkeeping 1211-1300. Journal of Accounting and Business Studies, Nr. 9, Vol. 2, 1973, s. 137-155.

28 Sulitková, Ludmila (ed.): Městské úředni knihy z Archivu města Brna 1343-1619. I. svazek. Knihy městského hospodaření. Knihy početní. Komorní počty 1467-1619. Brno 1999; Městské úřední knihy z Archivu města Brna 1343-1619. II. svazek. Knihy městského hospodaření. Knihy početní. Radní počty 1523-1619. Brno 2001; táž: Městské úředni knihy z Archivu města Brna 1343-1619. III. svazek. Knihy městského hospodaření. Knihy početní. Počty města a jeho zařízení 1468-1619. Brno 2003; táž: Vývoj městských knih v Brně ve středověku (v kontextu vývoje městských knih v českých zemích). Praha 2004.

29 Vaniš, Jaroslav: Kniha počtů královského města Loun z let 1450-1472 a 1490-1491. Praha 1979.

30 Detailní charakteristika a porovnání účetnictví v těchto městech viz Slavíčková, P.: Účetnictvi mezi tradici a racionalitou, s. 102-103.

31 Čarek, Jiří - Lůžek, Bořivoj: Názvoslovi městských knih v severozápadnich Čechách. Sborník archivních pracî 18,1968 , č. 2, s. 452-477. 
Registra continuata, Ausgabe, Ausgabsbuch, Ausgabregister, Einnahme, Hauptraitung, Hauptrechnung, Rechnungsbuch, Renthauptbuch, Stadtregister, Stadtrechnung a General Raitung alles Einkommens und Ausgabs. Skupiny zvláštních účetních knih městské správy tvoří rejstř́í příjmů a vydání na obnovení rady, rejstřík příjmů a vydání stavebního úřadu (Bauamt Register), rejstřík př́ijmu a vydání špitálu (Spittal Register), rejstřík vydání na tažení městské hotovosti, rejstřík vydání na ubytování vojska, rejstřík vydání na přehlídku vojska (Muster Register), rejstřík vojenské kontribuce, rejstř́k různých vojenských dávek (Quotta Register) a rejstř́ik příjmů a vydání na stravné pro vojsko a mimořádnou kontribuci (Empffang und Aussgab auf die Servitz Gelter and extra ordinarii Cassa). Do poslední skupiny pak byly zařazeny rejstřík příjmů a vydání za víno a jeho výčep (Weinambt Register), rejstřík koupě a prodeje soli (Salz Register), rejstřík příjmů a vydání cihelny (Register der Ziegelhütten), účetní knihy a rejstříky horní, příp. další druhy rejstříků, nikoli však ty, které se týkají městských statků, zemědělství. ${ }^{32} \mathrm{Z}$ hlediska účetní techniky by měly být do této řady zařazeny ještě knihy evidující městský majetek, a to zejména inventáře obsahující přehled movitého a nemovitého majetku města. ${ }^{33}$ Nicméně tento klíčový nástroj pro zjištování posunu (kladném či záporném) v hospodaření daného subjektu správní účetnictví, které bylo u nás používané v námi sledovaném období, na rozdíl třeba od účetnictví jednoduchého nedokázalo řádně využít. ${ }^{34}$

I přes široké spektrum různých účetních záznamů z období pozdního středověku a raného novověku, na které můžeme dnes v archivech narazit, většina měst jako základ používala jednu centrální knihu (rejstřík), jejíž označení mohlo být různé, jak můžeme vidět ve výše uvedeném výčtu. Nejednalo se o hlavní knihu ve smyslu účetnictví jednoduchého nebo podvojného, přesto se lze domnívat, že zejména ve starším období byla právě do ní koncentrována většina záznamů o finančních operacích, které město realizovalo. Bez zajímavosti není vztah této knihy - používejme pro ni označení kniha počtio - a purkmistrovských rejstř́k ů, se kterými bývá někdy v literatuře volně zaměňována. ${ }^{35}$ Rozdíl mezi nimi však může být pro intepretaci struktury a výsledků městského hospodářství klíčový. Na tuto skutečnost upozornil Miloslav Bělohlávek na prŕklad Mělníku. ${ }^{36}$ Tam se (nutno říci, že celkem výjimečně) dochovaly pro stejné období oba tyto typy účetních materiálů, a to navíc ještě spolu s řadou dalších (zvláštních) účetních knih a rejstříků. Díky tomu je možné sledovat použitý účetní mechanismus a udělat si tak mimo jiné představu o úplnosti účetnictví, která je jeho hlavní zásadou.

Nejstarší dochovaný purkmistrovský rejstřík v Mělníku pochází z roku 1539, v roce 1599 město založilo rejstř́ík obecních důchodů, ${ }^{37}$ do kterého bylo zapisováno až do roku

32 Tamtéž, s. 460-461.

33 Tamtéž, s. 459.

34 Detailně k roli inventáře v účetnictví viz: Slavíčková, P.: Účetnictví.

35 Viz např. Garkisch, Miloš: Potraviny a zemědělské produkty v nejstarši dochované berounské městské knize počtů. Středočeský sborník historický, 30-33, 2004-2007, s. 44-61; Stejskal, Aleš: Netolické městské účty 1596-1601. Od struktury k mikrohistorii. Zlatá stezka, 6, 1999, s. 173-184 aj.

36 Bělohlávek, Miroslav: Mělnické městské hospodářstvi před Bílou horou (Několik pohledů do finanční a hospodářské správy města). Časopis přátel společnosti starožitností 63, 1955, č. 1, s. 147-168.

37 Původní název zní: Registra na příjem obecního důchodu a vydání a předně od nebožtíka dobré paměti 
1606. Záznamy o příjmech a vydáních byly vedeny samostatně a děleny do rubrik (titulů, oddílů), přičemž některé rubriky byly během let sloučeny, celkově tedy docházelo spíš $\mathrm{k}$ jejich poklesu nežli nárůstu. Paralelně $\mathrm{s}$ tím byla $\mathrm{v}$ Mělníku vedena řada rejstř́íků, z nichž dochován je rejstřík purkmistrovský založený v témže roce a dále registra primaská z roku 1616 a několik rejstříků k různým sektorům městského hospodářství, jako byly registry viniční, obilní, solní, na železo, na prodej cihel a vápna. ${ }^{38}$ Podle Bělohlávka je lze rozdělit do dvou skupin, z nichž první obsahuje záznamy o hospodaření převážně s prostředky převedenými příslušnému úředníkovi z centrální městské pokladny, zatímco druhá skupina obsahuje záznamy o hospodaření, do kterého kromě částky přidělené centrální pokladnou přicházely peníze, a to většinově, z jiných (vlastních) zdrojů podnikání. Jednalo se právě o skupiny rejstř́ků primasa a purkmistrů. ${ }^{39}$ Samotná struktura těchto rejstříků byla obdobná jako u výše uvedené knihy obecních důchodů, mezi výdajovými rubrikami v registrech primaských najdeme i opravu radnice a další městské stavby, údržbu cest či hosty a reprezentaci. Jak je z mělnických záznamů zřejmé, bylo u těchto rejstříků v pravidelných intervalech prováděno vyúčtování, přebytek prostředků se převáděl do příjmů nového primasa (purkmistra), případný záporný rozdíl byl vyrovnán z centrální městské pokladny.

Podobné rejstříky nebo knihy purkmistrovských počtů se dochovaly v řadě dalších českých a moravských měst, mimo jiné v Českých Budějovicích, Olomouci, nebo třeba Náchodě. Určit, zdali se jedná o účetní knihu centrálního charakteru, nebo pouze knihu vedlejší obsahující záznamy určitého sektoru městské agendy, je v př́ípadě neúplného dochování účetní materie téměř nemožné. Nový pohled na purkmistrovský rejstřík v Olomouci z let 1566-1582 publikoval v nedávné době Bohdan Kaňák, podle kterého se jednalo o knihu zachycující př́ímy a výdaje určitého úseku městského hospodaření, nikoliv města jako celku. ${ }^{40}$ Další dochované prameny tohoto typu však na posouzení své role z hlediska použité účetní techniky ještě čekají. Je přitom třeba zohlednit i to, že stejný typ účetní knihy (rejstř́íku) mohl ve stejném městě v čase svoji funkci v účetnictví měnit, což intepretaci obsahu těchto pramenů jistě nijak neulehčuje. ${ }^{41}$ Nicméně z dlouhodobého hlediska docházelo ve městech stejně jako v případě další agendy také k ustálení struktury účetních materiálů a účetních záznamů obecně, k zavedení jednotného účetního systému však nedošlo dříve než v průběhu druhé poloviny 18. století.

Shrneme-li výše řečené, můžeme říci, že pro období středověku a raného novověku je nutné $\mathrm{k}$ pramenům účetního charakteru přistupovat s velkou obezřetností. V tomto období totiž neexistovala jednotná účetní pravidla či zvyklosti, které by byly plošně dodržovány. To ostatně můžeme demonstrovat už na samotném pojmu počty, který se v daném období sice používal pro označení toho, co my dnes chápeme jako účetnictví,

p. Benyamina Kutovce z Ourazu, JMti Císařové hofrychtére měst v království českém při obnově rady k letu Páně [15]99 založené zř́zeným důchodníkům Pavlovi Sobotovi, p. Matyáši Střelci z Lebnbergku a Janovi Smažíkovi.

Viz Bělohlávek, M.: Mělnické městské hospodářství, s. 148.

40 Kaňák, Bohdan: Počty purkmistrovské. In: Tajemství olomouckých městských knih, Olomouc 2014, s. 123-131. 
nejednalo se však o termín v pravém smyslu slova a konkrétní obsah výrazu mu dodával až kontext. ${ }^{42}$ Vzhledem k absenci jakékoliv legislativní úpravy se v praxi podoba účetnictví obvykle řídila konkrétními potřebami daného města a jeho správy a také zkušenostmi a schopnostmi konkrétního účetního (písaře). Nejednotnost a nestálost se přitom netýká pouze účetních pojmů, ale i účetních principů a struktury účetní materie. V tomto směru je nutné zohlednit i fakt, že každý účetní systém používá jiné schéma účetních principů a kategorií, které tvoří jeho podstatu. Identifikace účetní techniky a znalost podstaty účetního systému se proto při interpretaci historických účetních záznamů jeví jako klíčová.

\section{Historical Accounting Terminology in the Czech Lands in the Middle Ages and the Early Modern Period: Points forDiscussion}

The beginning of the Czech modern accounting terminology starts similarly as in other fields of study in the late 19th and early 20th century. The earlier periods could be characterized by the variability of accounting terminology. This variability very often transferred to works of historians, which can lead to a number of mistakes or misunderstandings. The aim of the article is to show, on the example of several accounting categories from the Middle Ages and the Early Modern Period, the need to discuss the historical accounting terminology in the Czech region, which has been absent so far in the Czech historiography. The article primarily focuses on the main accounting categories and their differences at first, such as incomes and revenues (př́ijmy and výnosy) and expenses and costs (výdaje a náklady). While in historical sources and accordingly in the works of historians the words incomes and expenses are used, from the accounting point of view they are revenues and costs. Similarly the total sum is very often regarded as the economic result, nevertheless in exact accounting terms it would be more likely a statement of the cash flow. Moreover the article discusses accounting terms in historical context, such as activum and passivum, profit and lost etc. Disadvantages of the administrative accounting technique used in the Middle Ages and Early Modern Period in the Czech lands are demonstrated on the structure of accounting books, especially in comparison with single-entry and Pacioli's double-entry bookkeeping. The recognition of the accounting technique seems to be crucial for the correct usage of accounting terms as well as interpretation of historical accounting records in general, which is the main output of the article. 